\title{
Stories from the Field Text Message from the Congo
}

\author{
Peter H. Kilmarx* \\ Fogarty International Center, National Institutes of Health, Bethesda, Maryland
}

\section{Baka tombi moyo wa disanka. Lufu lua buni be wa ebola. Udi ulua ngondo kayi bua hospital?}

That was the text message I received at my home in Atlanta from Shamba Gilbert, a traditional chief of Bakwa Tombe, a small village in the Democratic Republic of the Congo, at $2: 30$ Am on August 30,2007 . He wrote in a mixture of Tshikete, the local language, and Tshiluba, the regional language, but I could make it out to mean, "Bakwa Tombe greets you with pleasure. There is a lot of death from Ebola. When are you coming to build a hospital?"

I had been a Peace Corps volunteer in Bakwa Tombe from 1984 to 1986 . I was the first and only Westerner to live along the unpaved road stretching north and south $70 \mathrm{~km}$ between the towns of Mweka to the north and Luebo to the south, the seats of government of two zones in the Kasai Occidental region of the country. Bakwa Tombe was halfway in between, a village of about 1,000 people, subsistence farmers and their families. I lived in a mud hut with a thatched palm roof. No one, including me, had electricity, running water, or flush toilets. My job for 2 years was to introduce aquaculture, fish farming with Tilapia in hand-dug ponds to counter protein malnutrition, which was common in the region. At the end of 2 years, I was working with about 20 farmers in a $20-\mathrm{km}$ radius. I found it very challenging, especially the loneliness of being the only Westerner for $35 \mathrm{~km}$. There were no cellphones or landlines in Mweka in the 1980s. In 2 years, I had only one brief, expensive call home from the National Telecommunications office in Kinshasa, the national capital. My parents were able to come for a visit in 1985. They took turns riding on the back of my Yamaha $125 \mathrm{cc}$ motorcycle to visit the fish farmers and their ponds in the surrounding villages.

I had completed the premed requirements as an undergraduate but did not feel ready for medical school. I thought Peace Corps service would be an adventure and provide insight into my future. Within the first year, the farmers I worked with started naming their newborn sons after me. This was a big honor, and I was very saddened when one of the baby Pierres died, reportedly of measles. "How could someone die of measles when we have a vaccine?" I naively wondered, having recently received a booster shot. I started educating myself about public health and decided, yes, I was ready for medical school.

After the first year of medical school, I returned to Bakwa Tombe and conducted a survey of men's knowledge, attitudes, and practices related to HIV and AIDS, which was a relatively newly recognized phenomenon in Africa in 1987. I had many discussions with Chief Shamba, who noted that the

* Address correspondence to Peter H. Kilmarx, Fogarty International Center, National Institutes of Health, 31 Center Dr., Bethesda, MD 20892. E-mail: peter.kilmarx@nih.gov

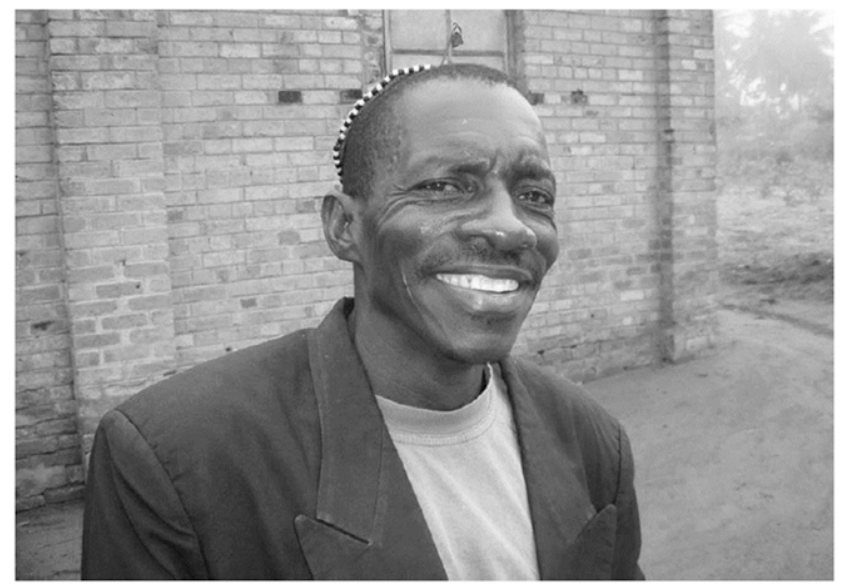

Chief Shamba Gilbert, traditional chief of Bakwa Tombe, Mweka zone, Kasai Occidental, the Democratic Republic of the Congo.

popular song "Attention na SIDA" (beware of AIDS) by the great Franco Luambo was very influential in changing men's behaviors, including his own. Shamba also became my most reliable correspondent; we exchanged letters every year or so about news from the village and our growing families.

Seven years later, after completing medical training, I joined the incoming 1994 class of the CDC Epidemic Intelligence Service, their 2-year postdoctoral training program. Near the end of my first year in 1995, there was a large Ebola outbreak in Kikwit in the Congo. Because I spoke French and was familiar with the country, I was deployed for a month to work with Congolese health officials and the WHO in the response. I worked under the expert direction of the CDC's Dr. Ali Khan with about 40 Congolese medical students on household surveillance, visiting the quarantined households of Ebola patients to immediately detect and isolate anyone who became symptomatic.

In June 2007, I received an annual update letter from Shamba. Remarkably, Shamba listed three mobile phone numbers in the letter. There was mobile cell service in Kasai Occidental! Shamba was working at the missionary hospital in Luebo, and we exchanged text messages and had a few short phone conversations, our first in 20 years.

When I received his 2:30 Am text message on August 30, 2007, I thought, "He's a village chief, what does Shamba know about Ebola?" and went back to sleep. The next morning I emailed Ali Khan and asked if they knew anything about an Ebola outbreak in the Congo. No, no one knew about an Ebola outbreak. I texted Shamba and told him to find the Luebo hospital director and call us. Several days later, we spoke with Dr. Mamba who described the cases with hemorrhagic signs and a high mortality rate. $A$ 
typical scenario was that family members would transport a patient to the hospital pushing him on a bicycle; then a few days later, they would also fall ill. We agreed that it sounded a lot like Ebola but needed a laboratory confirmation.

I spent the next few days preparing to travel to the Congo. Meanwhile, Dr. Bill Clemmer, the physician at the Bulape mission hospital north of Mweka, had collected blood samples and sent them to the CDC. On my way to the Atlanta airport, I received a call from Dr. Pierre Rollin who worked in the CDC Special Pathogens Laboratory. He let me know that Ebola had been detected in six of the 15 specimens they had received.

The CDC had a small office in Kinshasa, and they welcomed me onto their team when I arrived on September 12. Dr. Ginaluca (Luca) Flamigni, a gregarious Italian with a shaved head, was their medical epidemiologist. We established our CDC operations at the mission hospital in Luebo in midSeptember and were soon joined by about 10 members of the CDC Special Pathogens Branch. Three metric tons of laboratory equipment were transported by air from Atlanta, minor renovations of chosen laboratory space were completed, and specimen processing with same-day results began on September 27.

We also investigated the origin of the outbreak. We drove to the Makonoko Health Center between Luebo and Bakwa Tombe where the first cases had been reported and spoke with the nurse-director Mr. Emile Mbantshi who had reported the initial cases to his supervisors. We learned that the early suspect cases lived in a small village $12 \mathrm{~km}$ west of the Mweka-Luebo road. The day after we interviewed him, Emile rode on the back of my motorcycle, and with Luca on his motorcycle, we set out to the village in the forest, occasionally lifting our bikes over downed trees across the footpath. We met with the male elders present and learned that the village had a population of about 250 and a high poverty level with no school or health clinic. They reported very frequent hunting and consumption of bush meat, including monkeys and fruit bats.

One man asked if they should stop eating bats. This was not easy to answer. Our Peace Corps aquaculture project was intended to combat protein malnutrition, and conditions had worsened in the intervening decades. Bush meat was a significant source of protein for these villagers, and this was their first known Ebola outbreak. The most I felt comfortable saying was that they should not eat any dead animals they found and should wash their hands after butchering or handling raw meat. In retrospect, perhaps I should have given a stronger response. The same villages had another outbreak the following year with a nearly genetically identical virus.

The following day, my last full day in Luebo, Luca and I motorcycled $35 \mathrm{~km}$ north to Bakwa Tombe, my first visit in 20 years. This was a big event in the village with men wearing the village masks, warriors, and dozens of women in traditional dress dancing to the drums and with hundreds of onlookers. We sat on mats on the ground with the village chiefs under a palm thatch awning. Chief Shamba led the discussion and translated for me from Tshikete to French. The chiefs, bare-chested in raffia skirts and skullcaps, demanded that we build a hospital for them. I explained that it was one thing to build a building, but a hospital needs staff, medicine, equipment, running water, and electricity, which were still not present in the village. As they insisted, I replied that we had brought a laboratory to Luebo, Médecins Sans Frontières was providing medical care, and the Ebola case numbers were already declining. Realizing they were not going to get a hospital, the tension eased, and we talked more generally about the difficulties the village continued to face.

After saying our goodbyes, with no hugs or handshakes during an Ebola outbreak, Luca and I headed back south toward Luebo on our motorcycles. We stopped in Kabao, a small village $5 \mathrm{~km}$ along our way. As a dozen people crowded around to see who we were, a villager with a warm smile stepped forward and greeted me by name. He was Shamba Shamba, one of my last fish farmer recruits. He had two wives and had named a son after me. I asked him if he was still fish farming. He exclaimed, "Oui, c'est un bon travail!" (yes, it is good work!). He showed me a photo of Pierre, now 22 years old and a recent graduate of the University of Lubumbashi. Shamba said the fish farming had helped feed Pierre and pay for his school tuition. He asked me to wait and ran back to his tiny hut with thatched palm walls and roof. He came back with a small, thick, dog-eared Bible from which he pulled a photo of my mother holding newborn baby Pierre from when my parents had visited in 1985, 22 years earlier.

As we continued south on our motorcycles, there were tears in my eyes. My mother had died 5 years earlier, and her absence was still strongly felt. I was overcome with the enormity of the confluence of connections, coincidences, friendships, and struggles in our lives, personal and professional, to know and help each other and fight poverty, malnutrition, and disease.

Chief Shamba met me at the airstrip the next day. He had had a lung condition and was not well. He had been such a good friend and supporter when I was in the Peace Corps and had faithfully written to me almost every year since then. Now, he had reported an Ebola outbreak in his village and had helped educate the people about the risks of Ebola and how to prevent it by not touching ill persons or cadavers. In an epidemic response, speed is critical. In earlier Ebola outbreaks, there were months of delay before there was international awareness. But as a citizenepidemiologist, Shamba was able to send a text message, resulting in a CDC response in a matter of days. In a few years, he would be dead, but I would stay connected with his son, also named Pierre, who was born in 1988. I had learned from Shamba about what disaster responders call "community self-rescue." It can be a very powerful intervention to give people the basic knowledge and tools they need to help themselves. We saw this again when I was with the CDC in the Ebola response in Sierra Leone in 2014 and in Guinea in 2015 where transmission finally came under control when traditional leaders were educated and empowered to intervene.

As we said our last goodbye, I asked, "Shamba, you're a village chief. How did you know it was Ebola when you sent me the text message?" He replied, didn't I remember? After the Kikwit Ebola outbreak in 1995, 12 years earlier, I had written him a letter with a description of the clinical manifestations and epidemiology of Ebola. "If you ever see something that looks like this," I had written, "Let me know." 
For a more detailed version of this story, please check out the full version on ASTMH's blog at https://www.astmh.org/ ASTMH/media/Documents/Text-message-from-theCongo.pdf.

Received January 29, 2021. Accepted for publication February 1, 2021.
Published online March 8, 2021.

Disclaimer: The views expressed in this article are solely the responsibility of the author and do not necessarily represent the official views of the $\mathrm{NIH}$.

This is an open-access article distributed under the terms of the Creative Commons Attribution (CC-BY) License, which permits unrestricted use, distribution, and reproduction in any medium, provided the original author and source are credited. 